\title{
Moving beyond legal compliance: Innovative approaches to EU multi-level implementation
}

Eva Thomann

Fritz Sager

\section{Abstract}

Research on implementation in the European Union (EU) is characterized by a strong focus on legal conformance with EU policy. However, this focus has been criticized for insufficiently accounting for the implications of the EU's multilevel governance structure, thus providing an incomplete picture of EU implementation, its diversity and practice. The contributions of this collection represent a shift toward a more performance-oriented perspective on EU implementation as problem-solving. They approach implementation fundamentally as a process of interpretation of superordinate law by actors who are embedded within multiple contexts arising from the coexistence of dynamics of Europeanization, on the one hand, and what has been termed 'domestication', on the other. Moving beyond legal compliance, the contributions provide new evidence on the diversity of domestic responses to EU policy, the roles and motivations of actors implementing EU policy, and the 'black box' of EU law in action and its enforcement.

Keywords: Customization, domestication, Europeanization, implementation performance, multi-level implementation 


\section{Introduction}

This collection moves beyond legal compliance in European Union (EU) multi-level implementation research to shed light on alternative responses to superordinate law, practical implementation patterns, and mechanisms to ensure compliance in the EU. In response to increasingly complex and transboundary shared regulatory challenges, multi-level governance systems like the EU centralize steering tasks and delegate decision-making and/or execution competencies to different levels of territorial tiers - supranational (global and regional), national, regional (domestic), and local (Levi-Faur 2011: 11; Majone 1999). As Thatcher and Coen (2008: 806) point out, the 'implementation of public policies always raises questions of discretion and diversity'. Multi-level systems calibrate integration with member state discretion in order to implement common solutions to shared policy problems, tailormade to specific local contexts (Kissling-Näf and Wälti 2007; Pülzl and Treib 2007). This in turn should enhance the acceptance of centralized policies and, possibly, member state performance (Börzel and Hosli 2003; Elmore 1979; Keman 2000). The impact of such multilevel structures on policy outputs, outcomes and impacts is the subject of multi-level implementation research ever since Pressman and Wildavsky (1974) studied '[h]ow Great Expectations in Washington Are Dashed in Oakland'. Its currently dominant line is the rich body of literature on implementation in the EU and Europeanization.

In the quest to connect EU and domestic politics, seminal works on multilevel governance in the EU have amply scrutinized the EU's problem-solving capacity in terms of the impact of the EU on domestic institutions and policies at the national and local level (e.g., Featherstone and Radaelli 2003; Graziano and Vink 2008; Héritier 1999; Richardson 2012; Scharpf 1997). This collection contributes to this discussion. Its basic premise lies in understanding 
implementation as a core process in the problem-solving cycle. Hence, what is of interest here is the actual solutions to shared problems in the EU regulatory space (Knill and Tosun 2012). Implementation research has always held contradictory views on the role of discretion for policy success (Knill 2015; Pülzl and Treib 2007; Thomann et al. 2016). Accordingly, the question of what constitutes successful problem-solving is approached very differently by topdown and bottom-up implementation perspectives (Hill and Hupe 2014).

On the one hand, 'conformance implementation' refers to the degree to which the centrally decided blueprint is implemented from top to down (Barrett and Fudge 1981). This top-down school, which dominates Europeanization research, is primarily interested in comparing the intended and actually achieved outcomes of implementation, where the degree of the goal attainment serves as an indicator for implementation success (Knill 2015). Implicitly or explicitly, top-down perspectives tend to view discretion and the resulting deviations from the centrally decided rule as a control problem (Thomann et al. 2016). Alternatively, 'performance implementation' denotes whether a policy achieves outcomes that resolve the original policy problem at stake (Barrett 2004; Barrett and Fudge 1981; Mastop and Faludi 1997). This process-oriented bottom-up perspective emphasizes the role of policy implementers as problem-solvers, whose closeness to the source of the policy problem enhances their ability to achieve policy success (Elmore 1979). Hence, it is expected that policy instruments and goals may undergo context-sensitive modifications during the process of policy implementation. Implementers should have flexibility and autonomy for adjustment to facilitate learning, capacity-building and support-building in order to address policy problems. Ultimately, effective implementation is measured by the extent to which the perceived outcomes correspond with the preferences of the actors involved in the implementation 
process (Knill 2015). From this perspective, diverse approaches of problem-solving are actually an intended result of the decentralized implementation structures of multi-level systems (Joachim et al. 2007: 7).

However, we have very little systematic knowledge about this diversity of policy solutions (see however recently Bondarouk and Liefferink 2016; Sager et al. 2014; Thomann 2015a). Multilevel implementation research - in the EU and beyond - retains a strong top-down focus on member state compliance with central state decisions. A telling illustration is the title of a recent study which reads: 'You Can't Make Me Do It' (Haeder and Weimer 2013; see also Whitford 2007). This holds especially for Europeanization research, which is in its vast majority concerned with the question of whether EU directives are transposed into domestic law as required (see Angelova et al. 2012; Töller 2010; Toshkov 2010; Treib 2014). Accordingly, the past twenty-five years of EU compliance research have produced a fair amount of knowledge on the full or partial (non-) compliance with EU directives, the timeliness and correctness of transposition, the amount of non-compliance and transposition rates (Angelova et al. 2012; Töller 2010; Treib 2014). While undoubtedly relevant, several insights suggest that research on legal compliance gives us an incomplete picture of EU implementation.

Indeed, the emphasis on conformance implementation in EU research faces increasing critiques as it 'insufficiently captures the implications of member states being part of a multilevel system' (Schmidt 2008: 299), and 'tends to prejudge the EU as the main source of domestic change' (Börzel and Risse 2012: 2). As Knill (2015) highlights, this perspective relies on a highly simplified model of political steering and insufficiently takes into account the role, relevance and capacities of actors involved in the execution of a certain policy program. The compliance concept captures the degree of conformance implementation, but does not 
necessarily help us to understand performance (Thomann 2015a). Or, as Bondarouk and Liefferink (2016: 2) put it, the 'approach, by which compliance is juxtaposed to noncompliance, masks potentially great variance in responses between authorities and does not tell much about the extent of the domestic efforts to implement the policy'. In fact, there is growing evidence that under certain circumstances, legal compliance with EU law may be unrelated to its practical application (Falkner et al. 2005; Versluis 2003, 2007; Zhelyazkova et al. 2016). Accordingly, Treib (2014: 29) highlights that 'we have as yet comparatively little evidence on the extent to which there is non-compliance beyond transposition and on the factors that are conducive to effective application and enforcement'. However, if we accept the notion that any policy is only as good as its practical implementation (Hill and Hupe 2014; Thomann 2015b), then this leaves us with unsatisfactory knowledge about the actual problem-solving capacity of the EU (Scharpf 1997).

In summary, after decades of legal compliance research, much is known about the conformance at the legislative stage in the EU, but much less is known about performance in practice. Analyzing multi-level implementation beyond legal compliance has a high practical relevance not least because in the vein of economic modernization and globalization, policy problems have become increasingly complex transboundary and cross-sectoral, which has resulted both in an increased demand for regulation and in a blurring of the distinction between the global and the national (Levi-Faur 2011). Take, for instance, the enormous transformation of EU regulation in the past twenty years (Richardson and Mazey 2015). The latter has considerably expanded from a concentration on competition policy to coverage of many sectors (Thatcher and Coen 2008), and toward 'softer' governance modes (Newig and Koontz 2014; Radulova 2007). Notwithstanding the growing empirical relevance of EU rules, 
many aspects of EU implementation remain a black box, and 'the tendency to neglect issues of enforcement and application has even increased' (Treib 2014: 15). Against this background, it is vital to gain better empirical and theoretical understanding of the degree to which such multi-level systems are actually able to address the problems they are intended to solve in practice (Sparrow 2000). Not only Europeanization scholars, but also practitioners can benefit from such insights to improve policy outcomes.

\section{Contribution to the state of the art}

To fill these gaps, this collection presents innovative approaches to EU implementation that follow recent quests to move beyond legal compliance (Schmidt 2008). Therefore, the studies in this collection scrutinize other stages of the implementation cycle and adopt a more performance-oriented approach to EU implementation, from various angles. What unites them is their reassessment of the relative importance of EU policy, on the one hand, and domestic factors and actors, on the other hand in explaining the outcomes of EU implementation. Rather than focusing on compliance, they embrace the notion put forward by Bugdahn (2005: 177) that 'the implementation of EU policies is best conceptualized as a blend of effective EU influence over domestic policy choices in a given policy area - defined as Europeanization - and of domestic choices of non-prescribed or non-recommended policy options in the same policy area - which is termed domestication'. The contributions of this collection understand Europeanization and domestication as complementary forces, which jointly explain the multiple embeddedness of actors (Beyers 2005) involved in EU implementation. In this sense, the interplay between Europeanization and domestication is a central explanation for performance implementation. Furthermore, the contributions have as 
their entry point the notion that the 'transposition of EC directives is - to a very large extent -an act of interpretation' (Voermans 2009: 81). Emphasizing problem-solving and performance, these studies hence analyze implementation fundamentally as a process of interpretation of superordinate law by actors who are embedded within distinct and multiple contexts. In this vein, the collection addresses three closely intertwined sets of salient questions that research on legal compliance has left unaddressed.

A first crucial interest of this collection is to gain a better understanding of the different responses to superordinate law in the complex EU multi-level systems, apart from legal compliance. This entails two aspects: transposition outcomes other than conformance, as well as the question of how policy makers address the complexity of this system when deciding over implementation modes. Beyond legal compliance, very little is known about other possible transposition outcomes. Recent research suggests that member states differ notably in the substantial similarity of domestic policies (e.g., Bondarouk and Liefferink 2016; Steunenberg 2007; Sager et al. 2014) and that fully compliant member states go beyond the minimum requirements of superordinate law (Voermans 2009). Thomann (2015a) highlights the prevalence of the legitimate 'customization' of EU law and its implications for understanding member states as bottom-up problem-solvers. However, we still lack a systematic picture of the diversity of the 'European experience' (Majone 1999) - not least because research has hitherto invested little in the systematic conceptualization and operationalization of such transposition outcomes. It is only then that we can find out: what are the more fine-grained patterns of implementation in Europe, and can we identify underlying logics in this diversity (Thomann and Zhelyazkova, 2017 <THIS ISSUE: PUBLISHER TO ADD /UPDATE DETAILS AT PROOF>)? 
Analyzing the diversity of EU implementation is crucial in order to understand trade-offs between the well-explored conformance implementation and the more neglected performance implementation. This is all the more important as a single model of implementing structure does not exist in the EU (Peters 2014: 136; Richardson and Mazey 2015). Capturing the possible facets of multi-level implementation outcomes requires an analytic focus on the management of and responses to the complexity of such systems (Hooghe and Marks 2003; Sanderson 2006). While this 'multi-layer problem' (Hill and Hupe 2003) has long been recognized by implementation research, analytical solutions to it still need further development. In this context, several contributions have emphasized the potential for cross-fertilization between theoretical perspectives on EU implementation, on the one hand, and on policy implementation and comparative federalism, on the other (e.g., Barrett 2004; Börzel and Hosli 2003; Hill and Hupe 2014; Hooghe and Marks 2003; Keman 2000; Kissling-Näf and Wälti 2007; Knill and Tosun 2012; Knill 2015; Ongaro et al. 2010; Pülzl and Treib 2007; Sabatier and Mazmanian 1980; Whitford 2007; Winter 2003). Notwithstanding, attempts at connecting Europeanization theory with policy implementation theory are still rare (see recently Knill 2015). Taking this agenda further, Heidbreder (2017 <THIS ISSUE: PUBLISHER TO ADD /UPDATE DETAILS AT PROOF>) draws from implementation theory in order to identify different implementation types that are responsive to the complexity of the EU multilevel setting, depending on functional characteristics of the policy and the domestic setting at hand (Heidbreder 2011; Matland 1995).

After shifting the focus to performance at the legislative stage of implementation, the second interest of this collection lies in moving further down the implementation chain and opening the 'black box' of EU law in action (Versluis 2003, 2007). As individuals implementing public 
policies effectively act as decision-makers in their own right, understanding domestication implies to look at the practical implementation and enforcement of EU policy (Hill and Hupe 2014; Lipsky 1980/2010; Thomann 2015b). Our present knowledge on the practical implementation of EU law is scattered (e.g., Beunen et al. 2013; Falkner et al. 2005; Hartlapp and Falkner 2009; Héritier 1999; Versuis 2007). The most conclusive result so far is that the 'law in the books' is not necessarily the same as the 'law in action' (Treib 2014: 16; Versluis 2003) - a lesson which is also drawn in federalist settings (Kissling-Näf and Wälti 2007; Sager 2007). Previous results suggest that legal compliance levels sometimes tell us little about the degree and quality of the practical implementation of centralized law (Beunen et al. 2013; Falkner et al. 2005; Hartlapp and Falkner 2009; Zhelyazkova et al. 2016). This insight has important implications for practical implementation in terms of the patterns, mechanisms and actors involved that need exploration. However, accounting for practical implementation adds additional layers of complexity to implementation analyses, and implies a focus on the interaction of different governance levels (Egeberg and Trondal 2009; Exadaktylos and Radaelli 2012; Hill and Hupe 2003; Knill and Tosun 2012; Kuhlmann and Wayenberg 2016; Mavrot and Sager 2016). It also requires a systematic policy evaluation, which is resourceintensive, underdeveloped in many countries, and needs improvement in the EU (Knoepfel et al. 2011; Mastenbroek et al. 2016; Sabatier and Mazmanian 1980; Treib 2014). As a result of these obstacles, a crucial question remains to be explored: How does practical implementation - in terms of conformance and/or performance - look like in the EU multilevel system, and how can we explain it?

The current state of the art suggest that there are situations in which member states might decide to resolve problems independently of superordinate law (Barrett and Fudge 1981; 
Mastop and Faludi 1997). How do they perform such shifts from Europeanization to domestication in practice? To tackle this question, Dörrenbächer (2017 <THIS ISSUE: PUBLISHER TO ADD /UPDATE DETAILS AT PROOF>) analyzes the frontline implementation of EU immigration policy and uses insights from the behavioral public administration literature (Grimmelikhuijsen et al. 2017; Lipsky 1980/2010). Moreover, we hardly know how varying capacities for resilience determine member states' responses to problems, specifically if the latter are pronouncedly transboundary, such as air pollution which lack 'spatial fit' (Young 2002). While the potential of multi-level governance for improving policy implementation (rather than being an obstacle to it, see Leventon 2015) has been acknowledged in implementation theory (Hooghe and Marks 2003), the empirical question of whether this is actually the case on the ground has hardly been addressed in the EU literature. As Gollata and Newig (2017 <THIS ISSUE: PUBLISHER TO ADD /UPDATE DETAILS AT PROOF>) demonstrate, understanding these capacities implies taking a closer look at the horizontal and vertical cooperation and coordination between different levels of governance, with additional layers of governance being added in a federalist setting (see also Kuhlmann and Wayenberg 2016; Mathieu et al. 2016).

Jensen (2007) highlights that the effective practical implementation of EU policy is also a question of oversight and enforcement (Sager 2009). Simultaneously, as the EU has traditionally delegated these tasks to member states (Jans et al. 2015; see also Joachim et al. 2007; Perkins and Neumayer 2007), monitoring and enforcement can be expected to be a major source of domestication. The scarce existing evidence suggests that (the possibility of) oversight and enforcement is crucial for practical application in the EU, and that its absence leads to compliance deficits (Garoupa 2012; Jensen 2007; König and Maeder 2014; 
Zhelyazkova and Yordanova 2015). Scholten and Ottow (2014) also made first, sector specific steps toward a typology of EU enforcement mechanisms (see also Heidbreder 2015). However, Tosun (2012: 445) highlights the 'need for detailed descriptions of how these activities are actually pursued'. One reason why this is still missing is that the EU traditionally lacks enforcement competencies, and hence little encompassing data is available (Jans et al. 2015). Interestingly, however, recent years have witnessed a growing focus on the role of EU agencies and networks for improving the practical implementation of EU law, who formulate implementation guidelines for national agencies, inspect the implementation practices of national agencies, and provide training to national inspectors (see e.g. Egeberg and Trondal 2009; Groenleer et al. 2010; Versluis and Tarr 2013). Scholten (2017 <THIS ISSUE: PUBLISHER TO ADD /UPDATE DETAILS AT PROOF>) points to an ongoing trend toward Europeanization in this regard. The growing role of the EU in the field of direct enforcement can be explained by the problems that indirect enforcement faces; if the 'traditional' implementation of regulation by national authorities is failing, enforcement at the community level is likely to follow in the same policy area (Scholten and Scholten 2016).

In order to understand the mechanisms underlying patterns of diversity, practical implementation and enforcement, it is necessary to address a third question, namely that of the different roles and motivations of national actors implementing EU policy. Europeanization theory has a long tradition of assuming different logics of action - rationalist or norm-driven underlying implementing actors' behavior (Jupille et al. 2003; Mastenbroek and Kaeding 2006; March and Olsen 1998). Concurrently, it has been noted that actors implementing EU policy are also multi-hatted (Egeberg and Trondal 2009) in that they are expected to be loyal both to EU policy and to national policy. The discussion about a European administrative space has 
given rise to the question of whether there is such figure as the European public servant (Sager and Overeem 2015). As Mastenbroek (2017 <THIS ISSUE: PUBLISHER TO ADD /UPDATE DETAILS AT PROOF>, p. 2) notes, ' individual politicians and civil servants involved in compliance processes may vary in their propensity to comply with EU law (...). These individuals' stances towards EU law are likely to have consequences for their behavior, and thus for the functioning of the larger political-legal system in which they operate- in this case the European Union.' National implementation processes often serve the purpose to correct for what implementers perceive to be an inadequate balance between the two (e.g., Thomson 2010).

However, little is known about how the multiple embeddedness of actors in the EU multilevel system (Beyers 2005) creates diverse identities and problem perceptions, affects the interplay of these logics, and ultimately leads actors to lend different priorities to Europeanization and domestication, respectively. Part of the problem is that the focus on legal compliance in EU implementation research has also implied that the processes of administrative rulemaking, as well as the frontline implementation of EU rules, have been neglected (Treib 2014). As a result, our empirical knowledge about the importance of EU policy for implementing actors, relative to domestic policy, is limited. Empirical analyses of actors' motivations in the practice of EU implementation are urgently needed for a better understanding of the potentials and limits of Europeanization (Woll and Jacquot 2010). In this vein, Mastenbroek (2017 <THIS ISSUE: PUBLISHER TO ADD /UPDATE DETAILS AT PROOF $>$ ) analyzes an often neglected category of actors, namely legislative drafters and other EU-related legislative tasks, and the considerations that may or may not lead them to act as 'guardians' of EU law. Dörrenbächer (2017 <THIS ISSUE: PUBLISHER TO ADD /UPDATE DETAILS AT PROOF>) looks at the different 
motivations driving actors in referring to EU policy and domestic law, respectively when implementing EU migration policy at the frontline.

This collection explicitly seeks to move beyond the 'universe' of Europeanization research (Treib 2014) in order to benefit from the insights from different strands of literature. We intend to show that doing so can contribute importantly to overcoming the lack of cumulative, generalizable theoretical knowledge on the problem-solving capacity of multi-level systems (Hill and Hupe 2014; Pülzl and Treib 2007). In this vein, the contributions of this collection draw from neighboring fields, including general frontline and multilevel implementation theory (Dörrenbächer, 2017 <THIS ISSUE: PUBLISHER TO ADD /UPDATE DETAILS AT PROOF>; Heidbreder, 2017 <THIS ISSUE: PUBLISHER TO ADD /UPDATE DETAILS AT PROOF>), the literatures on regulatory change (Thomann and Zhelyazkova, 2017 <THIS ISSUE: PUBLISHER TO ADD /UPDATE DETAILS AT PROOF>), legislative ethics (Mastenbroek, 2017 <THIS ISSUE: PUBLISHER TO ADD /UPDATE DETAILS AT PROOF>), social psychology (Dörrenbächer, 2017 <THIS ISSUE: PUBLISHER TO ADD /UPDATE DETAILS AT PROOF>), multilevel governance (Gollata and Newig, 2017 <THIS ISSUE: PUBLISHER TO ADD /UPDATE DETAILS AT PROOF>) and regulation (Scholten, 2017 <THIS ISSUE: PUBLISHER TO ADD /UPDATE DETAILS AT PROOF>). Finally, the empirical studies presented here not only involve cross-sectoral comparison (Mastenbroek, 2017 <THIS ISSUE: PUBLISHER TO ADD /UPDATE DETAILS AT PROOF>; Thomann and Zhelyazkova, 2017 <THIS ISSUE: PUBLISHER TO ADD /UPDATE DETAILS AT PROOF>), they also explore neglected policy areas beyond environmental and social policies (Treib 2008; Töller 2010; Angelova et al. 2012), namely immigration policy (Dörrenbächer, $2017<$ THIS ISSUE: PUBLISHER TO ADD /UPDATE DETAILS AT PROOF>) and air quality policy (Gollata and Newig, 2017 <THIS ISSUE: PUBLISHER TO ADD /UPDATEDETAILS AT PROOF>). 


\section{Structure and content of the collection}

Following the different stages of the policy cycle, the collection begins by moving beyond legal compliance as a transposition outcome. Thomann and Zhelyazkova (2017 <THIS ISSUE: PUBLISHER TO ADD /UPDATE DETAILS AT PROOF>) set the stage by discussing conceptual considerations and empirical challenges faced by researchers engaging in the systematic comparative analysis of the 'customization' of EU law to depict diverse interpretations of EU rules beyond compliance. By conceptualizing this as a phenomenon of vertical regulatory change, they propose a generalized definition of customization and offer a flexible scheme for measuring customization both in quantitative and qualitative comparative settings. Their empirical analysis provides the first large-scale mapping of the customization of EU environmental and justice and home affairs policies in 27 member states. Next to revealing the considerable diversity of compliant transposition, they find that customization follows pronounced policy-specific EU regulatory logics.

The contribution by Mastenbroek (2017 <THIS ISSUE: PUBLISHER TO ADD /UPDATE DETAILS AT PROOF $>$ ) sheds light on the roles and strategies by administrative actors responsible for EU compliance. She scrutinizes the multiple roles of legislative drafters who are responsible for preparing the transposition of EU directives at the national level, and guarding the compatibility with 'autonomous' national legislation with EU legal injunctions. Specifically, she analyzes how these actors deal with their multiple roles resulting from their doublehattedness as guardians of EU law, on the one hand, and politically loyal national civil servants, on the other. Based on qualitative interviews with legislative drafters and their superiors in diverse Dutch ministries, she paints a nuanced picture of the role conceptions of these actors which guide their reinterpretation of EU law so as to integrate EU legal requirements with 
national policy objectives, and prioritize one over the other in case of incompatibilities.

The next two contributions deal with the practical implementation of EU policy. Gollata and Newig (2017 <THIS ISSUE: PUBLISHER TO ADD /UPDATE DETAILS AT PROOF>) empirically test the proposition underlying theories of polycentric governance, that multilevel governance is conducive to effective policy-making and delivery. This expectation is based on the arguments about the role of decentralization, spatial fit and participation, combined with a central planning and oversight mandate also known as 'mandated participatory planning'. Using the understudied case of the implementation of EU air quality legislation, they study all 137 air quality and action plans established since 2004 in German municipalities and agglomerations, as a case of a transboundary policy with a lack of spatial fit. Their analysis highlights the horizontal and vertical cooperation between different levels of government and administrative layers within the same policy arena. While this case does not suggest that multi-level governance improved policy delivery, it points to learning and capacity building between local implementers.

Moving further down the implementation chain, Dörrenbächer (2017 <THIS ISSUE: PUBLISHER TO ADD /UPDATE DETAILS AT PROOF>) 'zooms in' on individuals. Using concepts from social psychology, her analysis specifically focuses on the question what instrumental and normative motivations drive frontline bureaucrats to use EU law to solve the legal ambiguity arising from placing implementers in-between domestic and EU regulatory frameworks. Drawing on qualitative interviews with 21 frontline bureaucrats in ten German immigration agencies, Dörrenbächer's analysis provides rare insights into the concrete interplay of Europeanization and domestication when EU law is practiced next to national law. Her results suggest that these actors use EU law in situations when national regulations remain unclear. This reliance 
on EU law at the frontline can even correct for problematic transposition.

The contribution by Scholten (2017 <THIS ISSUE: PUBLISHER TO ADD /UPDATE DETAILS AT PROOF>) shows that while the power to enforce EU law has traditionally been the responsibility of EU Member States, the enforcement stage of the EU policy cycle has been moving towards 'Brussels' via the proliferation of EU entities with direct enforcement powers, EU enforcement networks and the use of EU hard, soft and case law. As Scholten highlights, this development raises the question of what role there is to play for the EU in the traditionally national field of EU enforcement. She discusses the implications for the EU's problem-solving capacity, as well as challenges posed for the legitimacy, accountability and practical effectiveness of EU enforcement.

The final contribution by Heidbreder (2017 <THIS ISSUE: PUBLISHER TO ADD /UPDATE DETAILS AT PROOF>) adopts a conceptual, bird's eye perspective that connects the dots between the complexity of EU implementation beyond compliance and general implementation research. Drawing on the distinction between top-down and bottom-up implementation and Hooghe and Mark's (2003) two types of multilevel governance, Heidbreder identifies four implementation types with distinct logics in the EU multilevel system: Centralization, agencification, convergence and networking. Based on Matland's (1995) ambiguity-conflict model of policy implementation, this enables her to derive causal expectations about which implementation type is functionally linked with strategic choices of policy-makers. Based on empirical illustrations, she discusses the descriptive and integrative capacity of her framework to systematically structure the different implementation practices in the EU and gain a better understanding of the potential pitfalls of its multi-level structure.

In the end, we wrap up the findings of the different studies and discuss their implications in 
view of the benefits of turning toward a more performance-oriented perspective on EU implementation as done in this collection (Thomann and Sager $2017<$ THIS ISSUE: PUBLISHER TO ADD /UPDATE DETAILS AT PROOF>). We draw preliminary conclusions about the interplay between Europeanization and domestication beyond compliance, while also formulating scope conditions, avenues for future research, and implications for practitioners.

\section{Biographical notes}

Eva Thomann, PhD, is a postdoctoral visiting fellow specialized in Europeanization, multilevel and frontline policy implementation at the Institute of Political Science, Heidelberg University, and the Department of Political and Social Sciences, European University Institute, Florence.

Fritz Sager, PhD, is a Professor of Political Science specialized in administrative studies and theory, policy research and evaluation, organizational analysis, and Swiss politics at the Center of Competence for Public Management at the University of Bern.

\section{Address for correspondence}

Dr. Eva Thomann

Institute of Political Science, Heidelberg University

Bergheimer Straße 58

DE-69115 Heidelberg 
E-Mail: eva.thomann@ipw.uni-heidelberg.de

\section{Acknowledgements}

The impetus for this special issue was born at the panel 'Innovative approaches to multi-level implementation research: Moving beyond legal compliance" at the 2nd International Conference on Public Policy in Milano, Italy, in July 2015. We are very grateful to all the participants, discussants and the referees for their valuable comments, and to the editors of JEPP for their advice and support in making this happen. Eva Thomann gratefully acknowledges financial support by the Swiss National Science Foundation, grants number P2BEP1-162077 and P300P1_171479. 


\section{References}

Angelova, M., Dannwolf, T. and König, T. (2012) 'How robust are compliance findings? A research synthesis', Journal of European Public Policy 19(8): 1269-1291.

Barrett, S. and Fudge, C. (1981) Policy and Action: Essays in the Implementation of Public Policy. London: Methuen.

Barrett, S. M. (2004) 'Implementation Studies: Time for a Revival? Personal Reflections on 20 Years of Implementation Studies', Public Administration 82(2): 249-62.

Beunen, R., Van Assche, K. and Duineveld, M. (2013) 'Performing failure in conservation policy: The implementation of European Union directives in the Netherlands', Land Use Policy (31): 280288.

Beyers, J. (2005) 'Multiple embeddedness and socialization in Europe: The case of Council officials', International Organization 59: 899-936.

Bondarouk, E. and Liefferink, D. (2016) 'Diversity in sub-national EU implementation: the application of the EU Ambient Air Quality directive in 13 municipalities in the Netherlands', Journal of Environmental Policy \& Planning, DOI:10.1080/1523908X.2016.1267612.

Börzel, T.A. and Hosli, M.O. (2003) 'Brussels between Bern and Berlin: comparative federalism meets the European Union', Governance 16(2): 179-202.

Börzel, T.A. and Risse, T. (2012) 'From Europeanisation to diffusion: introduction', West European Politics 35(1): 1-19.

Bugdahn, S. (2005) 'Of Europeanization and domestication: the implementation of the environmental information directive in Ireland, Great Britain and Germany', Journal of European Public Policy 12(1): 177-199.

Dörrenbächer, N. (2017) <THIS ISSUE: PUBLISHER TO ADD /UPDATE DETAILS AT PROOF> 
Egeberg, M. and Trondal, J. (2009) 'National agencies in the European administrative space: Government driven, commission driven or networked?', Public Administration 87(4): 779-790.

Elmore, R.F. (1979) 'Backward mapping: Implementation research and policy decisions', Political Science Quarterly 94(4): 601-616.

Exadaktylos, T. and Radaelli, C.M. (2012) Research design in European studies: establishing causality in Europeanization. Chippenham and Eastbourne: Palgrave Macmillan.

Falkner, G., Treib, O., Hartlapp, M. and Leiber, S. (2005) Complying with Europe: EU Harmonisation and Soft Law in the Member States. New York: Cambridge University Press.

Featherstone, K. and Radaelli, C.M. (2003) The politics of Europeanization. Oxford: Oxford University Press.

Garoupa, N. (2012) 'An economic analysis of legal harmonization: the case of law enforcement within the European Union', In Eger, T. and Schäfer, H.B. Research handbook on the economics of European Union law. Edward Elgar Publishing, pp, 279-288.

Gollata, J. and Newig, J. (2017) <THIS ISSUE: PUBLISHER TO ADD /UPDATE DETAILS AT PROOF>

Graziano, P. and Vink, M.P. (2008) Europeanization: New research agendas. Basingstroke: Palgrave Macmillan.

Grimmelikhuijsen, S., Jilke, S., Olsen, A. L. and Tummers, L. (2017) 'Behavioral public administration: Combining insights from public administration and psychology', Public Administration Review 77(1): 45-56.

Groenleer, M., Kaeding, M. and Versluis, E. (2010) 'Regulatory governance through agencies of the European Union? The role of the European agencies for maritime and aviation safety in the implementation of European transport legislation', Journal of European Public Policy 17(8): $1212-1230$.

Haeder, S. F. and Weimer, D. L. (2013) 'You Can't Make Me Do It: State Implementation of Insurance 
Exchanges under the Affordable Care Act', Public Administration Review 73(s1): S34-S47.

Hartlapp, M. and Falkner, G. (2009) 'Problems of operationalization and data in EU compliance research', European Union Politics 10(2): 281-304.

Heidbreder, E.G. (2017) <THIS ISSUE: PUBLISHER TO ADD /UPDATE DETAILS AT PROOF>

Heidbreder, E.G. (2015). 'Multilevel policy enforcement: Innovations in how to administer liberalized global markets', Public Administration 93(4): 940-955.

Heidbreder, E.G. (2011) 'Structuring the European administrative space: policy instruments of multilevel administration', Journal of European Public Policy 18(5): 709-727.

Héritier, A. (1999) Policy-making and diversity in Europe: Escape from deadlock. Cambridge: Cambridge University Press.

Hill, M. and Hupe, P. (2003) 'The multi-layer problem in implementation research', Public Management Review 5(4): 471-490.

Hill, M. and Hupe, P. (2014) Implementing Public Policy. London: Sage publications.

Hooghe, L. and Marks. G. (2003) 'Unraveling the central state, but how? Types of multi-level governance', American Political Science Review 97(2): 233-243.

Jans, J.H., de Lange, R., Prechal, S,. and Widdershoven, R.J.G.M. (2015) Europeanisation of Public Law. Groningen: Europa Law Publishing.

Jensen, C.B. (2007) 'Implementing Europe: A Question of Oversight', European Union Politics 8(4): 451477.

Joachim, J., Reinalda, B. and Verbeek, B. (2007) International organizations and implementation: enforcers, managers, authorities? Abingdon: Routledge.

Jupille, J., Caporaso, J.A. and Checkel, J.T. (2003) 'Integrating institutions: rationalism, constructivism, and the study of the European Union', Comparative Political Studies 36(1-2): 7-40. 
Keman, H. (2000) 'Federalism and Policy Performance. A Conceptual and Empirical Inquiry', In Wachendorfer-Schmidt, U. Federalism and Political Performance. London: Routledge, pp. 196227.

Kissling-Näf, I. and Wälti, S. (2007) 'The Implementation of Public Policies', In Klöti, U., Knoepfel, P., Kriesi, H., Linder, W., Papadopoulos, Y. and Sciarini, P. Handbook of Swiss Politics. $2^{\text {nd }}$ completely revised edition. Zurich: NZZ, pp. 501-524.

Knill, C. (2015) 'Implementation', In Richardson, J. und S. Mazey. European Union: power and policymaking. London und New York: Routledge, pp. 371-397.

Knill, C. and Tosun, J. (2012) 'Governance Institutions and Policy Implementation in the European Union', In Richardson, J. Constructing A Policy-Making State? Policy Dynamics in the EU. Oxford: Oxford University Press, pp. 309-333.

Knoepfel, P., Larrue, C., Varone, F. and Hill, M. (2011) Public Policy Analysis. Policy Press.

König, T. and Mäder, L. (2014) 'The strategic nature of compliance: an empirical evaluation of law implementation in the central monitoring system of the European Union', American Journal of Political Science 58(1): 246-263.

Kuhlmann, S. and Wayenberg, E. (2016) 'Institutional impact assessment in multi-level systems: conceptualizing decentralization effects from a comparative perspective', International Review of Administrative Sciences 82(2): 233-254.

Leventon, J. (2015) 'Explaining implementation deficits through multi-level governance in the EU's new member states: EU limits for arsenic in drinking water in Hungary', Journal of Environmental Planning and Management 58 (7): 1137-1153.

Levi-Faur, D. (2011) 'Regulation and regulatory governance', In Handbook on the Politics of Regulation. Cheltenham and Massachusetts: Edward Elgar, pp. 1-25.

Lipsky, M. (1980/2010) Street-Level Bureaucracy: The Dilemmas of the Individual in Public Services. 
New York: Russell Sage Foundation.

Majone, G. (1999) 'Regulation in comparative perspective', Journal of Comparative Policy Analysis: Research and Practice 1(3): 309-324.

March, J.G. and Olsen, J.P. (1998) 'The institutional dynamics of international political orders', International Organization 52(4): 943-969.

Mastenbroek, E. (2017) <THIS ISSUE: PUBLISHER TO ADD /UPDATE DETAILS AT PROOF>

Mastenbroek, E. and Kaeding, M. (2006) 'Europeanization Beyond the Goodness of Fit: Domestic Politics in the Forefront', Comparative European Politics 4(4): 331-354.

Mastenbroek, E., van Voorst, S. and Meuwese, A. (2016) 'Closing the regulatory cycle? A meta evaluation of ex-post legislative evaluations by the European Commission', Journal of European Public Policy 23(9): 1329-1348.

Mastop, H. and Faludi, A. (1997) 'Evaluation of strategic plans: the performance principle', Environment and Planning B: Planning and Design 24: 815-832

Mathieu, E., Verhoest, K. and Matthys, J. (2016) 'Measuring multi-level regulatory governance: Organizational proliferation, coordination, and concentration of influence', Regulation \& Governance, DOI:10.1111/rego.12127.

Matland, R.E. (1995) 'Synthesizing the implementation literature: The ambiguity-conflict model of policy implementation', Journal of Public Administration Research and Theory 5(2): 145-174.

Mavrot, C. and Sager, F. (2016) 'Vertical epistemic communities in multilevel governance', Policy \& Politics, DOI: https://doi.org/10.1332/030557316X14788733118252.

Newig, J. and Koontz, T.M. (2014) 'Multi-level governance, policy implementation and participation: the EU's mandated participatory planning approach to implementing environmental policy', Journal of European Public Policy 21(2): 248-267. 
Ongaro, E., Massey, A., Wayenberg, E. and Holzer, M. (2010) Governance and intergovernmental relations in the European Union and the United States: Theoretical perspectives. Edward Elgar Publishing.

Perkins, R. and Neumayer, E. (2007) 'Implementing multilateral environmental agreements: an analysis of EU Directives', Global Environmental Politics 7(3): 13-41.

Peters, B. G. (2014) ' Implementation structures as institutions', Public Policy and Administration 29(2): 131-44.

Pressman, J.L. and Wildavsky, A.B. (1974) Implementation. How Great Expectations in Washington Are Dashed in Oakland. Berkeley, Los Angeles, London: University of California Press.

Pülzl, H. and Treib, O. (2007) 'Implementing Public Policy', In Fischer, F., Miller, G.J. and Sidney, M.S. Handbook of Public Policy Analysis: Theory, Politics, and Methods. Boca Raton, FL: CRC Press/Taylor and Francis, pp. 89-107.

Radulova, E. (2007) 'The OMC: an opaque method of consideration or deliberative governance in action? ', European Integration 29(3): 363-380.

Richardson, J. and Mazey, S. (2015) European Union: power and policy-making. Routledge.

Richardson, J. (2012) Constructing a policy-making state? Policy dynamics in the EU. Oxford: Oxford University Press.

Sabatier, P. and Mazmanian, D. (1980) 'The Implementation of Public Policy: A Framework of Analysis', Policy Studies Journal 8(4): 538-560.

Sager, F. (2009) 'Governance and Coercion', Political Studies 57: 537-338.

Sager, F. (2007) 'Making transport policy work: polity, policy, politics and systematic review', Policy \& Politics 35(2): 269-288.

Sager, F. and Overeem, P. (eds.) (2015) The European Public Servant: A Shared Administrative Iden- 
tity? Colchester: ECPR Press.

Sager, F., Thomann, E., Zollinger, C. and Mavrot, C. (2014) 'Confronting theories of European integration: A comparative congruence analysis of veterinary drugs regulations in five countries', Journal of Comparative Policy Analysis: Research and Practice 16(5): 457-474.

Sanderson, I. (2006) 'Complexity, 'practical rationality' and evidence-based policy making', Policy \& Politics 34(1): 115-132.

Scharpf, F. (1997) 'Introduction: the problem-solving capacity of multilevel governance', Journal of European Public Policy 4(4): 520-538.

Schmidt, S.K. (2008) 'Beyond Compliance: The Europeanization of Member States through Negative Integration and Legal Uncertainty', Journal of Comparative Policy Analysis: Research and Practice 10(3): 299-308.

Scholten, M. (2017) <THIS ISSUE: PUBLISHER TO ADD /UPDATE DETAILS AT PROOF>

Scholten, M. and Ottow, A. (2014) 'Institutional Design of Enforcement in the EU: The Case of Financial Markets', Utrecht Law Review 10(5): 80-91.

Scholten, M., and Scholten, D. (2016) 'From Regulation to Enforcement in the EU Policy Cycle: A New Type of Functional Spillover?' JCMS: Journal of Common Market Studies, doi: 10.1111/jcms.12508.

Sparrow, M.K. (2000) The Regulatory Craft: Controlling Risks, Solving Problems and Managing Compliance. Washington, DC: Brookings Institution Press.

Steunenberg, B. (2007) 'A policy solution to the European Union's transposition puzzle: Interaction of interests in different domestic arenas', West European Politics 30(1): 23-49.

Thatcher, M. and Coen, D.( 2008) 'Reshaping European regulatory space: an evolutionary analysis', West European Politics 31(4): 806-836. 
Thomann, E. (2015a). 'Customizing Europe: transposition as bottom-up implementation', Journal of European Public Policy 22(10): 1368-1387.

Thomann, E. (2015b) 'Is output performance all about the resources? A fuzzy-set Qualitative Comparative Analysis of street-level bureaucrats in Switzerland', Public Administration 93(1): $177-194$.

Thomann, E., Lieberherr, E. and Ingold, K. (2016) 'Torn between state and market: Private policy implementation and conflicting institutional logics', Policy and Society 35(1): 57-69.

Thomann, E. and Sager, F. 2017) <THIS ISSUE: PUBLISHER TO ADD /UPDATE DETAILS AT PROOF>

Thomann, E. and A. Zhelyazkova (2017) <THIS ISSUE: PUBLISHER TO ADD /UPDATE DETAILS AT PROOF>

Thomson, R. (2010) 'Opposition through the back door in the transposition of EU Directives', European Union Politics 11(4): 577-96.

Töller, A.E. (2010) 'Measuring and comparing the Europeanization of national legislation: A research note', Journal of Common Market Studies 48(2): 417-444.

Toshkov, D. (2010) 'Taking stock: a review of quantitative studies of transposition and implementation of EU law', Institute for European Integration Research, Working paper No. 01/2010.

Tosun, J. (2012) Environmental Monitoring and Enforcement in Europe: A Review of Empirical Research, Environmental Policy and Governance 22: 437-448.

Treib, O. (2014) 'Implementing and complying with EU governance outputs', Living Reviews in European Governance 9(1).

Versluis, E. (2003) Enforcement matters. Enforcement and Compliance of European Directives in Four Member States. Delft: Eburon.

Versluis, E. (2007) 'Even rules, uneven practices: Opening the 'black box' of EU law in action', West European Politics 30(1): 50-67. 
Versluis, E. and Tarr, E. (2013) 'Improving compliance with European Union Law via agencies: The case of the European Railway Agency', Journal of Common Market Studies 51(2): 316-333.

Voermans, W. (2009) 'Gold-plating and double banking: an overrated problem? ', In Snijders, H. and Vogenauer, S. Content and Meaning of National Law in the Context of Transnational Law. Munich: Sellier European Law Publishers, pp. 79-88.

Whitford, A. (2007) 'Decentralized Policy Implementation', Political Research Quarterly 60(1): 17-30.

Winter, S.C. (2003) ' Implementation Perspectives: Status and Reconsideration', In: B.G. Peters and J. Pierre, eds. Handbook of Public Administration. Thousand Oaks: Sage, pp. 212-222.

Woll, C. and Jacquot, S. (2010) 'Using Europe: Strategic Action in Multi level politics', Comparative European Politics 8(1): 110-126.

Young, O.R. (2002) The institutional dimensions of environmental change: fit, interplay, and scale. MIT press.

Zhelyazkova, A. and Yordanova, N. (2015) 'Signalling 'compliance': The link between notified EU directive implementation and infringement cases', European Union Politics 16(3): 408-428 .

Zhelyazkova, A, Kaya, C. und R. Schrama. (2016) 'Decoupling practical and legal compliance: Analysis of member states' implementation of EU policy', European Journal of Political Research 55(4): 827-846. 